\title{
ACCOUNTING FOR SCIENCE: THE INDEPENDENCE OF PUBLIC RESEARCH IN THE NEW, SUBTERRANEAN ADMINISTRATIVE LAW
}

\author{
DONALD T. HORNSTEIN*
}

\section{INTRODUCTION}

The corporate accounting scandals of the early twenty-first century are stark reminders that "the map is not the territory." In the accounting scandals, stock valuations dropped when investors lost confidence in corporate earnings reports giving a true picture of the actual financial territories they purported to map. Currently, the White House Office of Management and Budget ("OMB") is putting the final touches on a new system of regulatory accounting, a system designed to account for the science used by federal agencies in their administrative missions. In light of the corporate accounting scandals, both the timing and shape of the new system of accounting for science are remarkable. It is as if nothing has been learned.

To be sure, OMB's program is sometimes explained simply as an attempt to improve the accuracy of regulatory science. But there are also reasons for concern that OMB's new programs could be used to skew the system by which regulatory science is generated in the first place. Worse, if abused, the new program could undermine precisely the type of independence in research that is currently seen as the necessary corrective policy on the corporate accounting side. Just when investment research departments are being insulated from undue influence, the new accounting for science is actually magnifying the influence corporations can have on what science tells us about the state of the world.

After detailing the legislative contours of OMB's new powers, including the scant record of Congress's deliberation over them, this Article analyzes their potential impact-both on the legal regimes affecting regulatory decisionmaking and, perhaps more fundamentally, on the institution of independent scien-

* Reef Ivey II Professor of Law, University of North Carolina School of Law, Chapel Hill.

1. The quotation, although popularized by British essayist Alfred North Whitehead, is attributed to Polish mathematician Alfred Korzybski. See Alfred KorZYBSKI, SCIENCE AND SANITY: AN INTRODUCTION TO NON-ARISTOTELIAN SYSTEMS AND GENERAL SEMANTICS 58 (4th ed. 1958). 
tific research itself. In Part II, this Article identifies within OMB's programs the expanded boundaries of a new, subterranean battleground in administrative law, one in which the scent of future regulation is caught by stakeholders who then battle to shape the scientific facts on which future regulation may be based. The result in administrative law terms is something akin to hard-look review taken across the dimension of time and space. Now, in the name of ensuring "good science," a very hard look indeed is applied almost at the moment of regulatory conception, when the first factual glimmerings of problems in the real world begin to be discerned by scientists. If a new term must be coined for this development, perhaps it should be known as the "withering-look" doctrine. So it is that William Kovacs, a vice president of the U.S. Chamber of Commerce, predicts that OMB's new programs "will have the most profound impact on federal regulations since the Administrative Procedure Act was enacted in 1946 . . by ensuring that [the Environmental Protection Agency] uses better science, and by giving industry additional grounds to sue."

In Part III, this Article discusses the danger to science itself. To be clear, the danger is not simply a heightening of the contest over what constitutes "good science" that has become such a fixture in health, safety, and environmental rulemaking. Rather, the danger involves a radical new level of disputation, in which warring stakeholders can reach back up the scientific pipeline to federally supported research laboratories and exert a distorting influence on what is generated in the first place and on what citizens can be told by agencies about the range of scientific opinion on matters of political concern. At its worst, the new program could support an official truth squad of political appointees at OMB to ensure that all science is "good" and a cadre of stakeholder vigilantes with the ability to harass scientific researchers who have produced results with which they disagree. It is little wonder then, that in contrast to the virtual absence of congressional deliberation, implementation of OMB's new programs has been opposed at various points by the American Association for the Advancement of Science, ${ }^{3}$ the National Academy of Sciences, ${ }^{4}$ the National Institutes of Health, ${ }^{5}$ the Council on Undergraduate Research, ${ }^{6}$ and the Association of American Universities. ${ }^{7}$

2. OMB Guidelines on Quality of Information Seen As Having Profound Impact on Agencies, 33 Env't Rep. (BNA) No. 3, at 146 (Jan. 18, 2002) [hereinafter Profound Impact].

3. See, e.g., Mary Ellen Sheridan, The University Community and the A-110 Proposed Revision, Remarks at the American Association for the Advancement of Science and Federal Focus, Inc.'s Briefing on OMB Revisions to Circular A-110 Regarding Public Access to Data (Feb. 26, 1999), available at $\mathrm{http} / /$ www.aaas.org/spp/dspp/sfrl/projects/omb/sheridan.htm (stating support for sharing of data generally, but noting that under the Shelby Amendment "the private sector could use the FOIA [Freedom of Information Act] tool for raiding basic research and scientific data that are being federally funded" causing "silence, because investigators would feel that they could not share with the agencies that had funded them what was happening in the laboratory").

4. At hearings before House Government Management, Information and Technology Subcommittee, Bruce Alberts, president of the National Academy of Sciences, and Harold Vamus, director of the National Institutes of Health, discussed "how the new law ... could force scientists to surrender incomplete and confidential information while inviting special interest groups to harass investigators 
The new programs, moreover, accelerate an already dangerous erosion in the independence of scientific research, especially on university campuses. In part because of reductions in public financial support, universities have been all too willing to participate financially in corporate-sponsored research on campus. In his (in)famous "report before leaving the Harvard presidency," Derek Bok "warned against [the increasing trend toward] entrepreneurial behavior by university" researchers and administrators. ${ }^{8}$ Numerous reports have concluded that universities often lack even the most basic internal mechanisms for assuring the independence of corporate-sponsored research on campus. ${ }^{9}$ Journals such as the Chronicle of Higher Education regularly cite examples of corporate pressure on university-based researchers. ${ }^{10}$ The new OMB programs exacerbate the problem. Among other things, one of the new programs opens potential pathways for influencing research supported with public funds, while leaving outside its ambit an equal concern for on-campus research funded solely by corporations. Yet the risks of error in environmental, health, and safety data-the justification for the new endeavors-are equally, if not more, likely to occur in corporate research. Corporate research can be influenced by result-minded corporate funders and, increasingly, by financial conflicts of interest in the researchers themselves. Thus, the design of the new accounting for science is startling. Precisely at the time when reformers are trying to purge corporate accounting from the distorting influence of underlying conflicts of interest, a new system of accounting for science is being implemented that aggravates just those types of distortions.

engaged in controversial or competing work." Joint Steering Committee for Public Policy, A-110/FOIA Issue (Mar. 23, 2000), at http://www.jscpp.org/A-110.htm [hereinafter Joint Steering Committee].

5. $I d$.

6. Letter from K. Elaine Hoagland, National Executive Officer, Council on Undergraduate Research, to Brooke Dickson, Office of Management and Budget (July 6, 2001), available at http://www.cur.org/wp_OMBreg.html [hereinafter Hoagland Letter] (responding to federal registry notice on data integrity and stating that "The Council On Undergraduate Research is concerned that this proposed rule, intended to ensure objectivity and integrity of information, would do just the opposite by allowing, even requiring, the tampering of data in the name of 'correcting' it").

7. Letter from Nils Hasselmo, President, Association of American Universities, and C. Peter Magrath, President, National Association of State Universities and Land Grant Colleges, to the Office of Management and Budget (Aug. 13, 2001), available at http://www.aau.edu/research/OMBLtr8.13.01 .html [hereinafter Hasselmo Letter] ("We believe the imposition of new, redundant tests and checklists that must be satisfied before information is released may be contradictory to the goal of transparency in government.... Furthermore, we are concerned that this test may provide still another avenue for interested parties to impede release by the government of material to which they object on political or economic grounds.").

8. Kenneth Sutherline Dueker, Biobusiness on Campus: Commercialization of University-Developed Biomedical Technologies, 52 FOOD \& DRUG L.J. 453, 483 (1997).

9. See, e.g., Rachel Zimmerman, Corporate Hand in Clinical Trials is Criticized, WALl ST. J., Oct. 24, 2002, at D8 (reporting that "according to a study [of 108 research institutions] published [that day] in the New England Journal of Medicine. . . . in many cases, research contracts between academic institutions and companies fail to adhere to minimal standards of accountability... . [and] that academic institutions rarely ensure that researchers participate in the design of the clinical trial and control editorial and publication decisions").

10. See infra notes $60,69,70,85$. 


\section{The DATA AMENDMENTS AND THE EMERGENCE OF THE NEW, SUBTERRANEAN ADMINISTRATIVE LAW}

\section{A. The Data Amendments}

At the core of OMB's new programs are two relatively short congressional amendments to appropriations bills. The first is a one-sentence amendment introduced by Senator Richard Shelby (R-AL) to a 4000-page fiscal year 1999 appropriations bill, often called the "Data Access" or "Shelby Amendment." The Shelby Amendment mandated an important change in OMB "Circular A110 ," which governs the conditions under which the federal government administers discretionary grants, including grants to university researchers made by the National Science Foundation, the National Institutes of Health, and other "awarding agencies." The Amendment directs "[t]he Director of OMB [to] amend[] Section .36 of OMB Circular A-110 to require Federal awarding agencies to ensure that all data produced under an award will be made available to the public through the procedures established under the Freedom of Information Act." ${ }^{12}$

However modest the Shelby Amendment's modification to Circular A-110 might appear, it had the effect of overturning Forsham v. Harris, ${ }^{13}$ a decision in which the Supreme Court concluded that "data generated by a privately controlled organization which has received grant funds from an agency ... but which data has not ... been obtained by the agency, are not 'agency records' accessible under the [Freedom of Information Act]." ${ }^{\prime 14}$ Despite having the effect of overturning twenty years of law and practice regarding grantee autonomy, the Shelby Amendment was all but invisible throughout the legislative process. Of course, there was (and still is) a legitimate, open public debate over the timing and scope of scientists' obligations to share their underlying data. ${ }^{15}$ There was little focused attention, however, on the Shelby Amendment when it sought to impose a federal solution onto this debate. The Shelby Amendment was not the subject of any contemporaneous committee hearings, ${ }^{16}$ and its leg-

11. Omnibus Consolidated and Emergency Supplemental Appropriations Act of 1999, Pub. L. No. 105-277, 112 Stat. 2681 (1998).

12. Id. The amendment further authorizes a reasonable fee for acquiring the data. Id. ("[I]f the agency obtaining the data does so solely at the request of a private party, the agency may authorize a reasonable user fee equaling the incremental cost of obtaining the data.").

13. 445 U.S. 169 (1980).

14. Id. at 178 .

15. See, e.g., Sheridan, supra note 3 ("First, let me firmly state that the university scientific community is the strongest voice for data access, for the right to use data in an unfettered way, and for the public dissemination of new knowledge.... [W] spend most of our time negotiating so that we ensure that privilege, and we uphold that academic principle when we interact with industry, the federal government, or any private sponsor.").

16. See, e.g., Senator Richard Shelby, Accountability and Transparency: Public Access to Federally Funded Research Data, 37 HARV. J. ON LEGIS. 369, 378-79 (2000) (referring to language in committee reports, colloquies on the Senate floor, language in bill, but not to contemporaneous hearings). The 
islative history otherwise consisted mostly of staged colloquies ${ }^{17}$ and a few cursory sentences in the various committee reports that accompanied the massive budget bill. ${ }^{18}$

When the Shelby Amendment became visible, it soon became evident that the silence with which it had been accompanied did not reflect unanimous scientific or political support. After OMB proposed specific revisions to Circular A-110 to implement the legislation in August 1999, it received over 3000 written comments in opposition, including written opposition on behalf of the National Science Foundation, the Association of American Universities, and the American Association for the Advancement of Science. ${ }^{19}$ Representatives Jim Walsh (R-NY) and David Price (D-NC) introduced a rider to the Fiscal Year 2000 Treasury and Postal Appropriations bill that would have postponed the Shelby Amendment's implementation, but it was rejected by the full House Appropriations Committee on a divided 22-35 vote, mostly along party lines. ${ }^{20}$ Two days after that defeat, hearings were begun before the House Government Management, Information, and Technology Subcommittee, to consider House Bill 88, introduced by Representative George Brown (D-CA), which would have repealed the Shelby Amendment for federal researchers. ${ }^{21}$ At those hearings, repeal of the Shelby Amendment was supported by, among other organizations, the National Academy of Sciences and the National Institutes of Health. ${ }^{22}$ But Representative Brown died the day after the hearings began, and House Bill 88 lost its impetus. ${ }^{23}$ To be sure, none of this undermines the inescapable fact that the Shelby Amendment was a validly enacted appropriations-bill rider and that it has survived at least two attempted repeals. It is equally clear, however, that at the time of its passage, the Shelby Amendment was mostly flying under the political radar screen.

following exchange occurred at a National Academy of Sciences workshop between Jim Tozzi of the Center for Regulatory Effectiveness and David Hawkins of the Natural Resources Defense Council:

Mr. Tozzi: First of all, the majority of the Senate and House looked at ... arguments to determine that the existing administrative procedures act and how you get that data was not sufficient.

Mr. Hawkins: Would you cite us the hearings that they undertook to do that?

Mr. Tozzi: I can give you committee reports. I am not an expert on hearings.

NAT'L ACAD. OF SCIENCES, WORKSHOP: SEekING ACCESS to RESEARCH DATA IN THE 21ST CENTURY (March 12, 2001), at 71-72, available at http://www7.nationalacademies.org/stl/Access

_Transcript_June_2001.doc [hereinafter NAS DATA ACCESS WORKSHOP].

17. See Shelby, supra note 16, at 378-79 ("At that time [October 9, 1998], Senators Lott, Campell, and I again engaged in a colloquy on the floor to discuss the challenges that were made in conference.").

18. See id.

19. See American Acad. of Arts \& Sciences, Center for Science, Technology \& Congress, Strong Response for Proposed Circular Change (June 1999), at http://www.aaas.org/spp/cstc/bulletin/articles/699/OMBA-110.htm [hereinafter Strong Response]; Efforts Underway to Block Implementation of Changes to OMB Circular A-110 (May 18, 1999), at http://globalchange.gov/policies/comments/ 0001.html.

20. See Joint Steering Committee, supra note 4.

21. $I d$.

22. $I d$.

23. $I d$. 
The other statutory basis for OMB's new programs had an equally innocuous beginning. Near the end of Congress's consideration of another massive appropriations bill, Representative Jo Ann Emerson (R-MO) introduced a short rider that added section 515 to the Treasury and General Government Appropriations Bill for Fiscal Year 2001. ${ }^{24}$ Section 515 addressed the subject of data quality, rather than data access, and, thus, is known as the "Data Quality Act." ${ }^{25}$ Section 515(a) of the Act directs OMB, by September 30, 2001, to issue "policy and procedural guidance to Federal agencies for ensuring and maximizing the quality, objectivity, utility, and integrity of information ... disseminated by Federal agencies. ${ }^{26}$ Section 515(b) then directs OMB to require federal agencies to adopt their own data quality guidelines within one year and establish administrative mechanisms by which "affected persons" can "seek and obtain correction of information ... that does not comply with the guidelines." ${ }^{27}$ As with the Shelby Amendment, the Data Quality Act hardly commanded widespread legislative attention. Even Dr. John Graham, the OMB official later appointed to be in charge of administering the statute, conceded that "the law was enacted as a rider to an appropriations bill without any hearings or extensive legislative history." 28

Given the lack of legislative history, one might well wonder about the design and regulatory philosophy underlying these laws. After all, as to data access, at

24. See Consolidated Appropriations Act of 2001, Pub. L. No. 106-554, § 515, 114 Stat. 2763, 2763A-153-154 (2000).

25. The Act is sometimes called the "Daughter of Shelby" by its critics. To be sure, there is some overlap between the two provisions. Dr. John Graham, the director of the Office of Information and Regulatory Affairs, has described the two statutes as "mutually reinforcing." NAT'L ACAD. OF SCI., ENSURING THE QUALITY OF DATA DISSEMINATED BY THE FEDERAL GOVERNMENT: WORKSHOP \# 1, at 9 (Mar. 11, 2002) [hereinafter NAS WORKSHOP, DAY 1], available at http://www7.nationalacad emies.org/stl/4-22-02_Transcript.doc (comments of John D. Graham). Nonetheless, to avoid confusion with the focus of the Shelby Amendment on data access, this Article does not refer to the Data Quality Act as the "Daughter of Shelby Act."

26. $\S 515,114$ Stat. $2763 \mathrm{~A}-153-154$.

27. Id. at 114 Stat. 2763A-154. Section 515(b) provides that the OMB guidelines shall:

(1) apply to the sharing by Federal agencies of, and access to, information disseminated by

Federal agencies; and

(2) require that each Federal agency to which the guidelines apply-

(A) issue guidelines ensuring and maximizing the quality, objectivity, utility, and integrity of information (including statistical information) disseminated by the agency, by not later than 1 year after the date of issuance of the guidelines under subsection (a);

(B) establish administrative mechanisms allowing affected persons to seek and obtain correction of information maintained and disseminated by the agency that does not comply with the guidelines issued under subsection (a); and

(C) report periodically to the Director-

(i) the number and nature of complaints received by the agency regarding the accuracy of information disseminated by the agency; and

Id.

(ii) how such complaints were handled by the agency.

28. NAS WORKSHOP, DAY 1, supra note 25, at 9; see also id. at 32 (statement of Alan Morrison, Visiting Professor of Law, Stanford Law School) ("The Data Quality Act is a statute that is quite short.... It is only a couple of paragraphs, and the good news and the bad news about the legislative history is the same news. There isn't any."). 
the time the provisions were enacted, general principles of administrative law gave interested persons fairly wide-ranging access to the facts, assumptions, and regulatory alternatives considered by agencies in carrying out their rulemaking functions. $^{29}$ As to data quality, agencies, particularly the Environmental Protection Agency ("EPA"), often had in place fairly dense systems of data-quality control, complete with internal peer-review mechanisms, scientific advisory committees, and the ability to enlist the aid of outside scientific institutions for quality checks. ${ }^{30}$

\section{B. The Emergence of the New, Subterranean Administrative Law}

Defenders of both the Shelby Amendment and the Data Quality Act (the "Data Amendments") are surprisingly transparent in, and indeed often openly boastful of, their shared opposition to government regulation on philosophical, rather than scientific, grounds. Thus, for example, when written comments on OMB's data access proposal were heavily trending in the direction of scientific organizations and others opposed to the Shelby Amendment, a counter-campaign of supporting letters was organized by such conservative groups as the National Rifle Association, the Eagle Forum, and the U.S. Chamber of Commerce. $^{31}$ The thinly veiled philosophical opposition to regulation was perhaps reflected best in letters sent from members of the Gun Owners of America, who supported aggressive implementation of the Shelby Amendment so as to "expose all the phony science used to justify many restrictions on firearms ownership." "32

It may have been Senator Shelby himself who revealed the link between his Amendment and broader, more political, disagreements over regulatory policy. Specifically, the Shelby Amendment grew out of a substantive disagreement with EPA over air pollution regulation. Writing with refreshing candor about

29. See, e.g., Nat'l Lime Ass'n v. EPA, 627 F.2d 416, 452 (D.C. Cir. 1980) (stating that judicial review of agency action "evince[s] a concern that variables be accounted for, that the representativeness of test conditions be ascertained, that the validity of tests be assured and the statistical significance of results determined"); Portland Cement Ass'n v. Ruckelshaus, 486 F.2d 375 (D.C. Cir. 1973) (stating that an agency must indicate in the rulemaking record "centrally important data" so that the public may make meaningful comments).

30. See, e.g., Donald T. Hornstein, Reclaiming Environmental Law: A Normative Critique of Comparative Risk Analysis, 92 COLUM. L. REV. 562, 574 (1992) ("Between 1975 and 1978, Congress authorized [EPA] to establish a Scientific Advisory Panel to review the scientific bases of pesticide risks, a Clean Air Scientific Advisory Committee to review the risk assessments underlying air quality standards, and the Science Advisory Board to review EPA's research initiatives and science-based policy determinations."). See generally SHEILA JASANOFF, THE FIFTH BRANCH: SCIENCE ADVISORS AS POLICYMAKERS (1990).

31. Strong Response, supra note 19.

32. Id. It was not unusual for gun-ownership organizations to pay attention to the role science can play in political disputes. In 1997, an article in the New England Journal of Medicine contended that the National Rifle Association tried to eliminate funding for the National Center for Injury Prevention and Control because of opposition to studies highlighting the dangers of keeping guns in the home. See Richard A. Deyo et al., The Messenger Under Attack-Intimidation of Researchers by Special-Interest Groups, 336 NEW Eng. J. MED. 1176 (1997) (citing J. Kassirer, A Partisan Assault on Science-the Threat to CDC, 333 NEW ENG. J. MED. 793 (1995)). 
the Amendment, Senator Shelby acknowledged that "[w]hile access to data and quality of data issues are not new, the pressing need for additional access was highlighted by the controversial National Air and Ambient Quality Standards ("NAAQS") rule on ozone and particulate matter proposed by [EPA] in 1997." ${ }^{33}$

EPA's proposed revisions of the ozone and particulate-matter NAAQSs were an undeniably visible part of the political landscape in 1997 and 1998. Because they raised the possibility of sweeping many of the country's urban and suburban areas into "nonattainment" status under the federal Clean Air Act, EPA's proposed rules faced a barrage of organized opposition, including highly visible congressional oversight hearings and the introduction of bills that would have specifically postponed revision of the standards. ${ }^{34}$ Thus, it is noteworthy that Senator Shelby, in his own explanation of the his Amendment, elaborated that it was not simply an intellectual commitment to data access that motivated his concern but instead his personal conviction that especially strong data were needed to outweigh the compliance costs of the new ozone and particulatematter rules. As the Senator put it:

[T]his wide disparity in potential costs fueled controversy over the data used to support the proposal .... My unsuccessful effort to gain public access to the data supporting the EPA's controversial NAAQS rule reinforced my belief that greater access to research data is necessary to ensure both that the best science is being used to support our federal rules and policies, and that federally funded agencies and researchers feel a greater sense of accountability to the public. ${ }^{35}$

The problem with Senator Shelby's concern over regulatory costs, of course, is that the Supreme Court squarely rejected it in February 2001 in Whitman v. American Trucking Associations, ${ }^{36}$ in which the Court upheld precisely these same ozone and particulate-matter rules and held that the Clean Air Act indeed forbids the balancing of compliance costs against evidence that regulation is needed to protect public health. ${ }^{37}$ The problem with Senator Shelby's concern over the scientific basis of EPA's standards is that the agency's actions here, too, have been validated-both in the courts and in subsequent scientific analysis. The precise scientific dispute over these NAAQSs deserves special discussion and is considered below. As to the most recent judicial determination, however, on remand from the Supreme Court, the D.C. Circuit unanimously

33. Shelby, supra note 16 , at 373.

34. See, e.g., Backers of Air Rules Claim Enough Support to Uphold Veto of Bill to Block Standards, 28 Env't Rep. (BNA) No. 15, at 654 (Aug. 8, 1997); EPA Not Backing Down on Air Standards As Discussions Continue at White House, 28 Env't Rep. (BNA) No. 7, at 301 (June 13, 1997); House Democrats Seek Talks With Clinton Over Proposed Changes to Ozone, PM Rules, 28 Env't Rep. (BNA) No. 1, at 5 (May 2, 1997); Missouri GOP Senators, Businesses Oppose Ozone, Particulate Standards, 27 Env't Rep. (BNA) No. 39, at 2022 (Feb. 7, 1997); Moderates in Senate Seek United Position on Proposals to Tighten Ozone, PM rules, 28 Env't Rep. (BNA) No. 6, at 262 (June 6, 1997); Ozone-PM Rules Survive Attack in Senate, Still Face Challenge in House This Year, 28 Env't Rep. (BNA) No. 28, at 1369 (Nov. 14, 1997).

35. Shelby, supra note 16 , at 373,376 .

36. 531 U.S. 457 (2001) [hereinafter Am. Trucking I].

37. Id. at $469-71$. 
upheld the revised ozone and particulate-matter NAAQSs against industry's arguments that the revisions were arbitrary and capricious. ${ }^{38}$ As to the particulate-matter standard, the court found that EPA had sufficient evidence after an "exhaustive rule-making process" to "substantiate[] its judgment regarding the inadequacy of the old particulate matter standards." ${ }^{39}$ As to the revised ozone standard of .08 parts per million ("ppm"), the court found that the agency had engaged in "reasoned decision-making" in following the advice of a majority of EPA's Clean Air Scientific Advisory Committee, which believed that the existing standard needed to be revised from its current $.12 \mathrm{ppm}$ to the $.07-.09 \mathrm{ppm}$ range. ${ }^{40}$

Yet, Senator Shelby may well get the last laugh. The American Trucking litigation is, in reality, a watershed event, framing especially well the dividing line between conventional administrative law and the emergence of the new, subterranean administrative law. Conventionally understood, the American Trucking litigation confirmed the "classic" administrative law vision of agency decisionmaking. Under this vision, perhaps the most widely noted element of the Supreme Court's American Trucking opinion was its unanimous endorsement of the current nondelegation doctrine. Here, the Court confirmed that Congress may delegate important discretionary policy-making tasks to agencies so long as, in the delegating legislation, Congress itself sets forth "intelligible principles" to guide agency action. ${ }^{41}$ With this holding, the Court had little trouble finding that the Clean Air Act contains just such broad principles, including Congress's unambiguous intent for EPA to vigorously set health-protective NAAQSs "with an adequate margin of safety," without consideration for the costs of adopting such standards. ${ }^{42}$ So too, on remand, the D.C. Circuit's American Trucking II opinion reflects the classic administrative law vision. Specifically, the Court found that Congress wanted EPA to act proactively in revising standards based on the "best available evidence," even if there remain some uncertainties in the science:

Thus, EPA's inability to guarantee the accuracy or increase the precision of the PM2.5 NAAQS in no way undermines the standards' validity. Rather, these limitations indicate only that significant scientific uncertainty remains about the health effects of fine particulate matter at low atmospheric concentrations. As the exhaustive rulemaking process makes clear... EPA set the primary NAAQS notwithstanding that uncertainty, just as the Act requires. ${ }^{43}$

Yet the conventional understanding, confirmed in the American Trucking litigation, of an expert agency following statutory principles to set timely, proactive, health-protective standards, no longer reflects the underlying reality. In fact, despite having "won" in 1997 the right to have proactively revised ozone

38. Am. Trucking Ass'ns v. EPA, 283 F.3d 355, 379 (D.C. Cir. 2002) [hereinafter Am. Trucking II].

39. Id. at 370-71.

40. Id. at $375-76,379$.

41. Am. Trucking I, 531 U.S. at 472.

42. Id. at 475-76.

43. Am. Trucking II, 283 F.3d at 370. 
and particulate-matter standards based on the best available evidence, EPA subsequently announced that its revised particulate-matter standard would "have no actual regulatory impact" until 2002 when further scientific analysis, including a study by the National Research Council ("NRC"), would retroactively confirm the wisdom of its action. ${ }^{44}$ Yet NRC's progress report in 2002 on restudying the effects of airborne particulates has only confirmed the wisdom of the revisions announced in 1997 by reinforcing the likelihood that as many as 15,000 excess deaths were-and are-occurring annually under the outdated standard. ${ }^{45}$ Thus, at least to the 75,000 statistical persons who since 1997 may have died preventable deaths under the old standard but who were able to enjoy none of the benefits projected under the revised standard, EPA's victories in court are cold comfort indeed.

The guerilla warfare that has in fact replaced the conventional model of agency action reflected in American Trucking is now institutionalized for all regulatory decisionmaking through the Shelby Amendment and the Data Quality Act. Indeed, the difference between the optimistic, and increasingly out-of-touch, conventional view of administrative action, and the new, subterranean administrative law was foreshadowed by the D.C. Circuit itself in American Trucking II. There, industry opponents of the revised standards argued that EPA's decisions were reversible for the agency's failure to release all "underlying data" from the studies on which the agency was relying that indicated public-health risks. The court was under no illusions about the burdens that would attend such a data-access requirement. As the court concluded:

[W]e agree with EPA that requiring agencies to obtain and publicize the data underlying all studies on which they rely "would be impractical and unnecessary." As EPA persuasively stated ... : "If EPA and other governmental agencies could not rely on published studies without conducting an independent analysis of the enormous volume of raw data underlying them, then much plainly relevant scientific information would become unavailable to EPA for use in setting standards to protect public health and the environment ...."46

The court's conclusions that nothing in conventional administrative law does, or should, require such hyper-analysis only serves as a counterpoint to the possibility that just such hyper-analysis in the name of "good science" is what will become de rigeur under the Shelby Amendment and the Data Quality Act.

In short, the way the game is played under the new, subterranean administrative law may now come to trump, in practical operation at least, the way the

44. Nat'l Acad. of Sciences, Background Information on "Research Priorities for Airborne Particulate Matter" (2002), at http://dels.nas.edu/best/pm/ (last visited June 24, 2003).

45. Id.; see also BD. OF ENVTl. Studies \& TOXiCOlOGY, NAT'L ACAD. OF SCIENCES, Estimating the Public Health Benefits of Proposed Air Pollution Regulations 9 (2002), available at http://books.nap.edu/books/0309086094/html/ [hereinafter NAS, PUBLIC HEALTH BENEFITS] ("Overall, the committee found that the epidemiological studies selected by EPA for use in its benefits analyses were generally defensible.").

46. Am. Trucking II, 283 F.3d at 372 (quoting 62 Fed. Reg. at 38,689). 
game was supposed to be played under the conventional American Trucking model.

\section{The Hyper-search for "Good Science" Under the Data Amendments}

It does not take long to worry about the institution of science amidst calls by policy-makers, many of them legally trained, for regulators to follow the answers given by "good science." Ostensibly, the call for good science rests on unease with adversarial systems - and, increasingly, a more deep-seated antipathy toward legal-political systems-for making decisions in which scientific information plays a role. The Supreme Court's decision in Daubert v. Merrell Dow Pharmaceuticals, Inc. ${ }^{47}$ if not a perfect metaphor for this position, is often used as a banner. For those carrying the banner, Daubert is read as contrasting the kind of "junk science" that can be procured by self-interested litigants in courtroom tort litigation with "good science" produced by disinterested scientists under the norms of the scientific method and peer review. Proponents of "good science" do not restrict their agendas to science in the courtroom. As this Symposium reflects, the banner is now raised to "Daubertize" administrative agencies. Indeed, the Data Amendments are regularly defended simply as measures to ensure that agencies, too, look only to "good science" for answers. ${ }^{48}$

Yet the lessons of EPA's ozone and particulate-matter revisions suggest that when "good science" is held up to a mirror, many of its proponents want only to see one thing-_my science." In fact, this result-oriented approach is nicely framed in industry's contrasting positions toward science in Daubert and the American Trucking litigation. In Daubert, industry opposed the introduction of testimony on the possibility of birth defects caused by Bendectin, an anti-nausea medication administered to pregnant women, because this testimony would have relied on theoretical inferences from animal-cell studies, live-animal studies, and chemical-structure studies. In the industry's view, the question of causation was properly framed only by peer-reviewed epidemiological studies of Bendectin's actual effects in the real world, which, it was argued, suggested little basis for finding Bendectin to cause birth defects in humans. ${ }^{49}$

In American Trucking, EPA based its action on the weight of just such peerreviewed, epidemiological studies-in that case suggesting some 15,000 to 20,000 excess deaths (and many thousands more episodes of excess disease) were occurring annually across the United States from exposure to ozone and particulates under the then-existing standards. Among these studies, EPA

47. 509 U.S. 579 (1993).

48. See, e.g., Shelby, supra note 16, at 376 (stating that the Shelby Amendment was designed to minimize the "use of 'junk science").

49. Leslie Morsek, Get on Board for the Ride of Your Life! The Ups, the Downs, the Twists, and the Turns of the Applicability of the "Gatekeeper" Function to Scientific and Non-Scientific Expert Evidence: Kuhmo's Expansion of Daubert, 34 AKRON L. REV. 689, 704 n.58 (2000) (discussing the Bendectin litigation and contrasting the industry's reliance on "information published on Bendectin" resulting from "tests based on human statistics" and the testimony of plaintiff's experts based on animal-cell studies, live-animal studies, and chemical structure analysis). 
relied on the so-called "Six Cities Study," which was a twenty-year longitudinal collection of studies measuring air-pollution effects among thousands of people in diverse settings - a massive research effort that alone had spawned over 100 publications. ${ }^{50}$ Dr. Douglas Dockery, one of the principal investigators of the Six Cities Study, later testified to a workshop of the National Academy of Sciences that "what we found was that, even as we adjusted for sex, age, and cigarette smoking, occupation, education, obesity, and chronic disease history, people living in areas with higher air pollution, as determined by the fine particle concentrations, had a shorter life expectancy than people living in the cleaner cities." $" 51$

Throughout the congressional hearings in 1997 over EPA's proposed revisions, industry critics and their congressional allies repeatedly sought to challenge the Six Cities Study on numerous grounds: failure to adequately consider other possible confounding factors, failure to precisely define a safe ambient level for particulates, and lack of access to the data "underlying" the study, apparently including the detailed confidential medical information provided to the researchers by thousands of citizen-participants. For present purposes, what matters is not the likelihood that any of these objections had merit (which is discussed below) but instead the complete sea-change in industry's objections to precisely the type of peer-reviewed epidemiology that had been held up as the gold standard in Daubert. Of course, what had changed in the case of air pollution was that the results of the science did not favor industry. The only "good science" apparently was "my science."

Still, the furor over EPA's revised standards might have reflected only the not-uncommon occurrence of organized opposition to an agency's rulemaking. The story might have ended simply with concessions by EPA to these political realities. Certainly, such concessions were made. During its rulemaking process, although EPA refused to obtain and release the confidential medical information underlying the Six Cities Study, the agency did agree to direct an independent evaluation of the study by the Health Effects Institute ("HEI"), a respected scientific organization partially funded by the automobile industry. The Harvard researchers allowed the HEI access to the underlying data, and the HEI confirmed after review both the study's methodology and its substantive results. ${ }^{52}$ EPA also agreed (perhaps in light of the American Trucking litigation then pending) to postpone implementation of its revised standards until its next five-year NAAQSs review, scheduled for 2002. The D.C. Circuit completed the American Trucking litigation in March 2002 by upholding the scientific underpinnings of EPA's revisions from attack on arbitrary-and-capricious grounds. ${ }^{53}$ In the meantime, however, congressional opponents of implementa-

50. See Am. Trucking II, 283 F.3d at 364-65; see also NAS DATA ACCESS WORKSHOP, supra note 16 , at $24-26$.

51. Id. at 28 .

52. See Elizabeth Adelman, Data Wars: How Superseding Forsham v. Harris Impacts the Federal Grant Award Process, 21 J. NAT'L Ass'N AdMIN. L. JudgES 105, $105-06$ (2001).

53. Am. Trucking II, 283 F.3d at 379. 
tion of the revised standards included $\$ 46.6$ million in yet another appropriations bill for a second, "independent" analysis of the health effects of particulate matter, this time by the National Academy of Sciences. ${ }^{54}$ In July 2002, the NRC published a preliminary review that, although suggesting any number of refinements for the long-term study of particulate matter, otherwise supported the general validity of the science underlying EPA's revised standards. ${ }^{55}$ It bears repeating that those standards are necessary to address some 15,000 early deaths caused by the existing unhealthy levels of air pollution we still breathe today.

The real story of the revised NAAQSs battle, however, was that its opponents were so result-oriented that they suggested mechanisms-the Data Amendments-designed to intersect the underlying scientific process by which results such as these could be generated in the first place. Thus, rather than rely on the virtues of peer review as an indicator of scientific reliability as they had in Daubert, proponents of "good science" now regularly note the limitations of peer review amidst their suggestions that something else is needed. ${ }^{56}$ For example, rather than rely on the virtues of scientific review by independent organizations, as they did in demanding review of the Six Cities Study by the HEI and then the National Academy of Sciences, proponents of "good science" now argue that any member of "the public" should be allowed access to any study referenced by agencies and that any "affected person" should be allowed to lodge objections to data quality with agencies, with those objections in turn reviewable not by independent scientific organizations but by OMB and, perhaps, Members of Congress. ${ }^{57}$ Lest anyone doubt the possibility that within these new arrangements, "good science" can be attacked until it resembles "my science," William Kovacs of the United States Chamber of Commerce, when asked what he would do if given access to the data underlying the Harvard Six Cities Study (data that has been twice corroborated by independent analyses) responded simply, and undoubtedly honestly, that he would re-analyze it. ${ }^{58}$

To appreciate the possibilities of corporate pressure on publicly funded researchers through the Data Amendments, one need only consider the extent to which, as a general matter, the shape and content of university-based research has already been subject to corporate pressure.

54. Id.

55. NAS, PUBlic HeAlth BENEFITS, supra note 45, at 4.

56. Thus, Senator Shelby explains the need for data access: "The scientific community itself has acknowledged that peer review can vary widely in quality and outcome.... [I]ndeed, the peer and agency review process has proved to be insufficient as a means of validating data." Shelby, supra note 16 , at 375 .

57. See Pub. L. No. 106-554, § 515, 114 Stat. 2763, 2763A-154 (Data Quality Act) (2000) (permitting "affected persons" to make data-quality objections); Pub. L. No. 105-277, 112 Stat. 2681 (Shelby Amendment) (1998) (requiring underlying data to be made available to "the public").

58. Profound Impact, supra note 2, at 147. 
III

\section{THE GENERAL INCREASE IN CORPORATE INFLUENCE OVER RESEARCH}

\section{A. The Status Quo}

To set the stage for a brief analysis of university-based research, it is worth elaborating how significant the growth has been in corporate-sponsored research on campus. To some extent, this is a function of a reduction in federal financial support for university research (which fell between 1969 and 1990 from over $19 \%$ to $12 \%),{ }^{59}$ not to mention the reduction in overall public financial support for colleges and universities in general (which fell, for example, in Canada from $60 \%$ in 1980 to $40 \%$ in 1999) ${ }^{60}$ By necessity, therefore, universities have had to look elsewhere for support. Corporations' interests in university-based research in the United States undoubtedly also stem from the BayhDole Act of 1980, ${ }^{61}$ which allowed universities to patent the results of research that had been funded through federal grants, thereby opening the possibility of earning royalties by licensing innovations to private corporations. ${ }^{62}$ Before 1980, universities were producing about 250 patents per year; in 1998 alone, universities produced over 4800 patent applications. ${ }^{63}$

There is no mistaking an increase in the research relationships between private corporations and universities. An editorial in the journal Science noted that, as of 1996, corporate funding had grown markedly to comprise up to $7 \%$ of "overall university research" budgets. ${ }^{64}$ For research in the life sciences generally, estimates of the share of corporate funding in the mid-1990s ranged between $9 \%{ }^{65}$ and $11 \%{ }^{66}$ At some universities, corporate research support is higher. At the Massachusetts Institute of Technology, for example, even in 1986 industrial funding comprised $15 \%$ of the overall research budget, and at Carnegie-Mellon University, this figure was $23 \% .^{67}$ There are also particular areas where corporate support is especially marked. In the field of biomedical research, between 1980 and 2000, corporate funding grew to comprise $62 \%$ of

59. Melissa S. Anderson, The Complex Relations Between the Academy and Industry, 72 J. HIGHER EDUC. 226, 231 (2001).

60. Paul Desruisseaux, Canadian Professors Decry Power of Companies in Campus Research, Chron. Higher EDUC., Nov. 12, 1999, at A59.

61. Patent and Trademark Law Amendments Act, Pub. L. No. 96-517, 94 Stat. 3015 (1980).

62. See Council on Governmental Relations, The Bayh-Dole Act: A Guide to the Law and Implementing Regulations (Sept. 1999), at http://www.cogr.edu/bayh-dole.htm.

63. Anderson, supra note 59, at 234.

64. Dorothy S. Zinberg, Editorial, A Cautionary Tale, 273 SCIENCE 411, 411 (1996).

65. David Blumenthal et al., Participation of Life-Science Faculty in Research Relationships with Industry, 335 NEW ENG. J. MED. 1734, 1738 (1996) (using 1995 data).

66. David Blumenthal et al., Relationships between Academic Institutions and Industry in the Life Sciences-An Industry Survey, 334 New ENG. J. MED. 368, 369 (1996) (using 1994 data).

67. Wayne Biddle, Corporations on Campus, 237 SCIENCE 353, 353 (1987). 
spending on such research nationally. ${ }^{68}$ The medical school at Washington University in St. Louis has a formal arrangement with Monsanto that has, since 1982, produced $\$ 150$ million in basic-research money for the university. ${ }^{69}$ In 1998, the College of Natural Resources at the University of California at Berkeley announced a five-year, \$25 million "strategic alliance" with Novartis (since absorbed by Syngenta) that provides to every participating professor in the Berkeley plant-biology department annual awards ranging from $\$ 60,000$ to $\$ 200,000$. $^{70}$

The trend does not necessarily reflect a one-sided scenario of industries seducing otherwise innocent academic departments. Universities, for their part, are often more eager than corporations to form alliances. The Berkeley-Novartis arrangement, for example, was instigated by the university itself when Gordon Rausser, Dean of the Natural Resources College, sent inquiries to sixteen agricultural, biotechnology, and life sciences companies. ${ }^{71}$ A published study of university-business partnerships revealed that, as a general matter, universities were too eager to enter into such partnerships because they were "overestimating the opportunities for financial gain and underestimating the financial risks." observed that universities "appear less and less as charitable institutions seeking the truth and serving students and more and more as huge commercial operations that differ from corporations only because there are no shareholders and no dividends." 73

The linkage between industry and business does not necessarily mean a reduction in scientific quality. Despite the severity of his outgoing assessment of the trend, Bok had claimed in the 1980s that "the participation of Harvard and its professors in commercial ventures can be structured in ways that are wholly consistent with its academic values.",74 And in 1996, Bok was quoted for the somewhat less alarming prediction that, "the price of corporate support is eternal vigilance." 75 Nor was Bok alone in this relative complacency: only three of fifty-nine respondents to a survey of academic researchers in 1997 believed that "the costs of academic capitalism [were] in excess of benefits."

68. Robert Lee Hotz, Medical Tests Skewed, Study Finds, L.A. TIMES, Jan. 22, 2003, at A14 (reporting on a study by Yale University researchers published in the Journal of the American Medical Association).

69. Goldie Blumenstyk, Berkeley Pact With a Swiss Company Takes Technology Transfer to a New Level, CHRON. HiGHER EDUC., Dec. 11, 1998, at A56.

70. Goldie Blumenstyk, A Vilified Corporate Partnership Produces Little Change (Except Better Facilities), CHRON. HighER EduC., June 22, 2001, at A24.

71. Blumenstyk, supra note 69.

72. NORMAN E. BowIE, UNIVERSITY-Business PARTNERSHIPS: AN ASSESSMENT 57 (1994).

73. Dueker, supra note 8, at 483 (quoting Derek Bok).

74. Id. (quoting Derek Bok).

75. Zinberg, supra note 64, at 411 (quoting Bok's statements at a seminar on university-industry relations).

76. Anderson, supra note 59 (citing Slaughter \& Leslie). 
There is also evidence, however, that the link between universities and commercial ventures creates the potential for bias in commercially financed research. There is, of course, some anecdotal evidence of outright pressure on university researchers by their corporate funders. An article in the journal Science in November 2000 illustrated just such a dispute involving university-based researchers Drs. James Kahn and Stephan Lagakos. ${ }^{77}$ Kahn and Lagakos, who had been asked to evaluate a large clinical trial of HIV-related medication, alleged that the corporate funder of the trial tried to block publication of their study, which had found that the drug provided no clinical benefit, unless the study included the company's analysis that some of the data indicated that the drug could help some people. ${ }^{78}$ Other anecdotal evidence can also be found. ${ }^{79}$

The bigger concern, however, involves the possibility that corporate sponsorship influences the mindset of university researchers, who edit themselves lest they jeopardize their sponsors. Drummond Rennie, an editor at the Journal of the American Medical Association, believes that many academic researchers, unlike Kahn and Lagakos, would "keep quiet to avoid angering corporate sponsors." ${ }^{80}$ Marcia Angell, former editor of the New England Journal of Medicine, says that industry influence has so distorted medical literature that she refers to this as the "misinformation age" of medical research. ${ }^{81}$ In one study, faculty spoke frequently about how the pursuit of competitive funding "altered the ethos of departments and entire universities." ${ }^{" 82}$ Another study of the problem concluded:

Many different types of relationships may exist between sponsors of research studies and independent investigators. A sponsored research agreement allows the author to retain control over the publication of study results. A consulting agreement may not give explicit publication rights to the investigator or author. Consulting agreements can also be designed to require the author to submit the manuscript for publication only after the sponsor reviews the manuscript and provides written permission for publication. Generally, sponsored-research agreements are designed to protect the academic integrity of the study. While the research produced under these agreements may not appear different to the journal or to the reader, the sponsorship agreement may serve to limit the publication of findings that are "negative" from the sponsor's perspective. $^{83}$

77. $I d$.

78. Carol Cruzan Morton, Company, Researchers Battle Over Data Access, 290 SCIENCE 1063, 1063 (2000).

79. See, e.g., Constance Holden, Brown Doctor Protests Firing, 277 SCIENCE 483, 483 (1997) (describing allegations by David Kern, an occupational health doctor, that he lost his job due to a dispute involving his corporate funder's attempt to prevent him from publishing research); Douglas M. Birch \& Gary Cohn, Standing up to Industry, BALT. Sun, June 26, 2001, at 1A (reporting Dr. William Applegate's allegations of pressure from corporate sponsors seeking to influence his evaluation of a calcium channel blocker).

80. Birch \& Cohn, supra note 79.

81. Id.

82. Anderson, supra note 59, at 226.

83. Kevin Schulman et al., Ethics, Economics, and the Publication Policies of Major Medical Journals, 272 JAMA 154, 154 (1994). 
Such concerns seem to be borne out by at least some statistical evidence. A recent study covering over 1000 peer-reviewed scientific papers found that "[i]ndustry-sponsored research is 3.6 times more likely to produce results favorable to the company that helped pay for it." ${ }^{\text {"84 }}$ A study published in 1998 was reported to find that " 96 [percent] of the researchers who wrote favorable articles about a controversial class of drugs for treating hypertension and angina also had financial ties to the makers of those drugs .... [whereas] [a]mong those who published articles critical of the drugs, only 37 [percent] had financial ties." ${ }^{85}$ Yet another study published in 1998 found that scientists receiving gifts from the biosciences industry often "think that donors place restrictions and expect returns that may be problematic for recipients as well as institutions." Perhaps the best indirect evidence that bias can creep into "nonlitigation" research is the position taken by numerous scientific institutions and journals requiring disclosure of researchers' financial conflicts of interest. The leading medical journals all have such disclosure requirements. ${ }^{87}$ The voluntary Uniform Requirements for Manuscripts Submitted to Biomedical Journals recommends such disclosures. ${ }^{88}$ In February 1999, the Association of American Medical Colleges adopted similar guidelines on conflicts of interest. ${ }^{89}$ The policies of the National Science Foundation, the Public Health Service, and the Food and Drug Administration ("FDA") also recognize the potential bias that can exist in sponsored, nonlitigation research..$^{90}$ As the FDA has said, its regulations reflect a growing consensus in the scientific community "that certain financial arrangements between clinical investigators and product sponsors, or the personal financial interests of clinical investigators, can potentially bias the outcome of clinical trials." ${ }^{.11}$

84. See Hotz, supra note 68 .

85. Goldie Blumenstyk, Conflict-of-Interest Fears Rise as Universities Chase Industry Support, Chron. Higher EduC., May 22, 1998, at A41, A42 (reporting on a January 1998 study in the New England Journal of Medicine).

86. Eric G. Campbell et al., Looking a Gift Horse in the Mouth: Corporate Gifts Supporting Life Sciences Research, 279 JAMA 995, 997 (1998) (finding, inter alia, that 63\% of recipients "thought that donors expected acknowledgment in publications" and that $32 \%$ "thought donors expected prepublication review of articles or reports" stemming from the gift).

87. Patterson, supra note 51, at n.102 (citing the requirements of the New England Journal of Medicine, the Journal of the American Medical Association, and the Lancet); see also Sheldon Krimsky \& L.S. Rothenberg, Financial Interest and Its Disclosure in Scientific Publications, 280 JAMA 225, 226 (1998).

88. $I d$.

89. Id. at n.160.

90. Financial Disclosure by Clinical Investigators, 21 C.F.R. $\S 54.1(b)$ (2002); Financial Disclosure by Clinical Investigators, 63 Fed. Reg. 5233-01 (Feb. 2, 1998) (to be codified in 21 C.F.R.); Responsibility of Applicants for Promoting Objectivity in Research for Which PHS Funding is Sought, 42 C.F.R. $\S$ 50.601-.606 (2002).

91. Financial Disclosure by Clinical Investigators, 59 Fed. Reg. 48,708 (proposed Sept. 22, 1994) (to be codified in 21 C.F.R.). 


\section{B. How the Data Amendments Can Threaten Non-Corporate-Funded \\ Research and Exaggerate the Potential Bias in Corporate-Funded Research}

The influence corporations can wield today in the context of contractual university-corporate research endeavors becomes generalized under the Data Amendments. Now, that influence can extend even to research that is supported by public funds. The Shelby Amendment, for example, gives anyone the right to seek access to research that is wholly supported by public, but not corporate, funds. The prospect of organized, public relations campaigns to discredit the science that these objectors do not believe to be "good" is hardly farfetched..$^{22}$ A 1995 editorial in the New England Journal of Medicine related what the author considered a partisan attack on the National Center for Injury Prevention and Control ("NCIPC"), a center at the national Centers for Disease Control that researches the public-health aspects of injuries, by "the Heritage Foundation (a conservative think tank), the Doctors for Integrity in Research and Public Policy (an anti-gun-control physicians' group), and the National Rifle Association." ${ }^{93}$ The Doctors for Integrity group posted a message on the Internet arguing for a cut-off of NCIPC funding so as to "end the bogus 'public health' assault on our civil rights" that came from NCIPC's "incompetent and politicized science." In April 1997, a "Sounding Board" article in the New England Journal of Medicine entitled "The Messenger Under Attack-Intimidation of Researchers by Special-Interest Groups" reported on other examples of what the authors saw as organized attacks on scientific findings. ${ }^{95}$ That article elicited correspondence on similar incidents published in the October 30, 1997 issue of the Journal under a collection entitled "Intimidation of Researchers by Special-Interest Groups. ${ }^{\prime 96}$

The use of the Data Amendments to attack science with which one disagrees is already beginning to unfold. So it is that the U.S. Chamber of Commerce, despite industry's loss in the American Trucking litigation, is considering

92. See Joint Steering Committee, supra note 4 (stating the concerns of the National Academy of Sciences and the National Institutes of Health that the new law could "invite[] special interest groups to harass investigators engaged in controversial or competing work"); supra Hoagland Letter, note 6 (stating the concerns of the Council on Undergraduate Research that data integrity rules "would do just the opposite by allowing, even requiring, the tampering of data in the name of 'correcting' it"); Hasselmo Letter, supra note 7 (stating the concern of the Association of American Universities that guidelines on research data could "provide still another avenue for interested parties to impede release by the government of material to which they object on political or economic grounds").

93. Jerome P. Kassirer, A Partisan Assault on Science-The Threat to the CDC, 333 NEW ENG. J. MED. 793, 793 (1995).

94. Id.

95. Deyo, supra note 32, at 1176-77 (alleging "coordinated attacks at scientific meetings and skillful manipulation of the procedures for investigating scientific misconduct" in attacks on researchers working on the health risks of lead exposure, interest-group attacks on scientists researching multiple chemical sensitivity, and the use of the Freedom of Information Act by the pharmaceutical industry to demand of one researcher "all records relating to study design and methodology, study protocol(s), individual data for all study results and data, ... meeting minutes, [and] notes").

96. Intimidation of Researchers by Special-Interest Groups, 337 NEW ENG. J. MED. 1314 (1997) (letters to the editor including correspondence both critiquing and amplifying the anecdotes reported by Deyo et al., supra note 32). 
filing a new lawsuit under the Data Amendments over EPA's revised ozone and particulate-matter standards. ${ }^{97}$ So it is that the Center for Regulatory Effectiveness ("CRE"), an industry-supported entity specializing in overseeing agencies' implementation of the Data Amendments, filed comments with OMB in November 2002 seeking to ensure that data quality issues are adequately addressed before the National Highway Traffic Safety Administration informs the public through a new "Early Warning" program of the possibility of emerging dangers from automotive defects. ${ }^{8}$ And so too has the CRE filed a correction request under the Data Quality Act protesting a statement referencing "endocrine effects in various organisms including frogs" in an EPA risk assessment of the widely used herbicide atrazine. In the CRE's view, the studies on which EPA's reference was based were not sufficiently validated, ${ }^{99}$ even though those studies had been published in prestigious, peer-reviewed journals. ${ }^{100}$ The CRE had also threatened to sue the Department of Energy for what it believed to be foot-dragging in adopting data quality guidelines ${ }^{101}$ until, approximately one month later, the CRE received an advance copy of the Department's guidelines. As the CRE announced on its webpage, these guidelines met with CRE's approval because they adopted a particular standard of "quality" from the Safe Drinking Water Act that, in CRE's view, would be useful in evaluating the science of global climate change. ${ }^{102}$ In February 2002, the CRE argued to the White House Office of Science and Technology Policy that the National Assessment of Climate Change, which had been developed by multiple agencies, failed to meet OMB's data quality guidelines. ${ }^{103}$

97. See EPA Proposed Guidance on Data Quality Draws Fire From Industry, Advocacy Groups, 26 Chem. Reg. Rep. (BNA), No. 26, at 878, 879 (July 1, 2002) ("William Kovacs, vice president of environment and regulatory affairs at the chamber, told reporters June 21 that the chamber is considering filing a lawsuit to challenge data EPA used as it determined in 1997 to tighten air pollution emissions to reduce ozone and particulate matter.").

98. Center for Regulatory Effectiveness, Comments Re: Reporting of Information and Documents About Potential Defects, Retention of Records 49 CFR Part 579, OMB No. 2127-0616 (Nov. 6, 2002), at http://www.thecre.com/pdf/20021126_cre-nhtsa.pdf; see also Ricardo Alonso-Zaldivar, Release of Auto Safety Data is Disputed, L.A. TIMES, Dec. 13, 2002, at C9 (reporting industry's concern that agency's quarterly Internet updates would disclose sensitive information that could be misused and "could create an adversarial atmosphere that undermines safety").

99. See Center for Regulatory Effectiveness, Kansas Corn Growers Association \& The Triazine Network, Request for Correction of Information Contained in the Atrazine Environmental Risk Assessment, Docket No. OPP-34237A (Nov. 25, 2002), at http://www.thecre.com/pdf/petition-atrazine2B.pdf.

100. See Carl T. Hall, From Boyhood Curiosity to Scientific Discovery-Biologist Links Pesticides to Amphibian Deformities, S.F. CHRON., Nov. 4, 2002, at A6, available at http://www.ourstolenfuture.org/ Commentary/News/2002/2002-1104-SFC-hayes.htm (stating that studies by Tyrone Hayes appeared in the journal Nature and in the Proceedings of the National Academy of Sciences).

101. Group Threatens to Sue Energy Department for Not Releasing Data Quality Guidelines, 26 Chem. Reg. Rep. (BNA), No. 25, at 854 (June 24, 2002).

102. See DOE's Proposed Data Quality Guidelines Said to Include Ideas Not in Other Plans, 26 Chem. Reg. Rep. (BNA), No. 30, at 976, 977 (July 29, 2002).

103. Id. 


\section{IV}

\section{CONCLUSION}

In moving towards about "Daubertizing" federal agencies, the Shelby Amendment and the Data Quality Act run the risk of delegitimizing "good science" as the kind of goal to which no one would otherwise object. Science is an enormously important public resource in a free society, and there are, accordingly, enormous benefits in maintaining public confidence in its underlying integrity as a process. Whatever possible upside the Data Amendments may have in expanding the ability of nonscientists to correct the occasional and inevitable scientific mistake, the possible downside of creating a world in which science is perceived as just another category of "spin" are undoubtedly much more profound. Dr. Allan Bromley, a nuclear physicist at Yale and former science advisor to President George H.W. Bush, may have had it only partly right when he stated about the then-existing federal budget surplus: "No science[,] no surplus." 104 The more fundamental possibility is "no science, no freedom." There is already sufficiently worrisome evidence of growing, undue influence on the integrity of scientific inquiry. The Data Amendments threaten to make a political and judicial football out of a core public resource-the institution of scientific inquiry itself. The Data Amendments should be repealed. 